\title{
Intramolecular Hydrogen Bonding and Electronic Structure of Thiadiazole Annulated Hemihexaphyrazine
}

\author{
Arseniy A. Otlyotov, ${ }^{@}$ Anton P. Merlyan, Vladimir V. Veretennikov, \\ Alexander E. Pogonin, Evgeny N. Ivanov, Yana E. Filippova, Yuriy A. Zhabanov, ${ }^{\circledR}$ \\ and Mikhail K. Islyaikin ${ }^{\circledR}$
}

\section{Dedicated to Professor Oleg Aleksandrovich Golubchikov on the occasion of his 70-th birthday}

Institute of Macroheterocycles, Ivanovo State University of Chemistry and Technology (ISUCT), 153000 Ivanovo, Russian Federation

@Corresponding authors_E-mails: arseney_otlyotov@mail.ru,zhabanov@gmail.com,islyaikin@isuct.ru

\begin{abstract}
Different tautomeric structures of thiadiazole annelated hemihexaphyrazine (TDAHHp) were considered using DFT in B3LYP/pcseg-2 approximation. Energetics of the intramolecular hydrogen bonding was quantitatively estimated by means of NBO and AIM calculations and according to the NBO analysis results, the most energetically favorable tautomer of TDAHHp surprisingly turned out to possess the lowest total H-bond stabilization energy. The results are compared with that for the previously studied hemihexaphyrazine - 2,3,5,10,12,13,15,20,22,23,25,30-dodecaazahexaphyrin $\left(\mathrm{C}_{30} \mathrm{H}_{15} \mathrm{~N}_{15} \mathrm{~S}_{3}\right)$. Electronic absorption and infrared spectra were simulated for the most favorable tautomer of TDAHHp.
\end{abstract}

Keywords: Hemihexaphyrazine, hydrogen bond, electronic spectrum, NBO, AIM.

\section{Внутримолекулярные водородные связи и электронное строение тиадиазол-аннелированного гемигексафиразина}

\author{
А. А. Отлётов, ${ }^{@}$ А. П. Мерлян, В. В. Веретенников, А. Е. Погонин, \\ Е. Н. Иванов, Я. Е. Филиппова, Ю. А. Жабанов, ${ }^{\circledR}$ М. К. Исляйкин ${ }^{\circledR}$ \\ Посвящается профессору Олегу Александровичу Голубчикову \\ по случаю его 70-летнего юбилея
}

\begin{abstract}
НИИ Макрогетероциклических соединений, Ивановский государственный химико-технологический университет, 153000 Иваново, Россия

@E-mails: arseney_otlyotov@mail.ru,zhabanov@gmail.com, islyaikin@isuct.ru
\end{abstract}

\begin{abstract}
C помощью DFT расчетов в приближении B3LYP/pcseg-2 изучень семь таутомеров тиадиазол-аннелированного гемигексафиразина (ТDАННр). Энергия внутримолекулярных водородных связей в таутомерах оценивалась с использованием двух различных подходов: NBO анализа распределения электронной плотности и топологической теории AIM. На основе результатов NBO-расчетов сделано неожиданное заключение о том, что наиболее энергетически выгодный таутомер ТDАННр характеризуется минимальной суммарной энергией внутримолекулярных водородных связей. Результаты расчетов сопоставлены с результатами ранее изученного гемигексафиразина - 2,3,5,10,12,13,15,20,22,23,25,30-додекаазагексафирина $\left(C_{30} H_{15} N_{15} S_{3}\right)$. Для наиболее энергетически предпочтительного таутомера TDAHНр проведены TDDFT расчеты электронных переходов. Смоделирован инфракрасный спектр исследуемого соединения на основе квантово-химических расчетов.
\end{abstract}

Ключевые слова: Гемигексафиразин, водородная связь, электронный спектр поглощения, NBO, AIM. 


\section{Introduction}

Investigations of the molecular structure and tautomeric behaviour of macroheterocyclic systems have been the subject of the many recent studies. ${ }^{[1-6]}$ Commonly used DFT calculations often allow to establish the most energetically favorable tautomer and then the preference is discussed in light of fundamental concepts of chemistry. Intramolecular hydrogen bonding is one of the most important issues among them for such objects. However, it is essential to put general considerations on the quantitative basis. One of the most popular approaches for quantitative estimation of the phenomenon of hydrogen bonding nowadays was developed in AIM theory and it is focused on the locating so-called "bond critical points" (BCPs) corresponding to hydrogen bonds. Besides, in the recent study of Vogt et al., ${ }^{[7]}$ the energy of a weak hydrogen bond was estimated based on the results of the NBO analysis. Both approaches are used in the present study for thiadiazoleannelated hemihexaphyrazine (TDAHHp) macroheterocycle (Figure 1). They are demonstrated to provide a different point of view on the observed tautometic behaviour as compared to the previously studied $2,3,5,10,12,13,15,20,22,23,25,30$-dodecaazahexaphyrin $\left(\mathrm{C}_{30} \mathrm{H}_{15} \mathrm{~N}_{15} \mathrm{~S}_{3}\right) \cdot{ }^{[5]}$

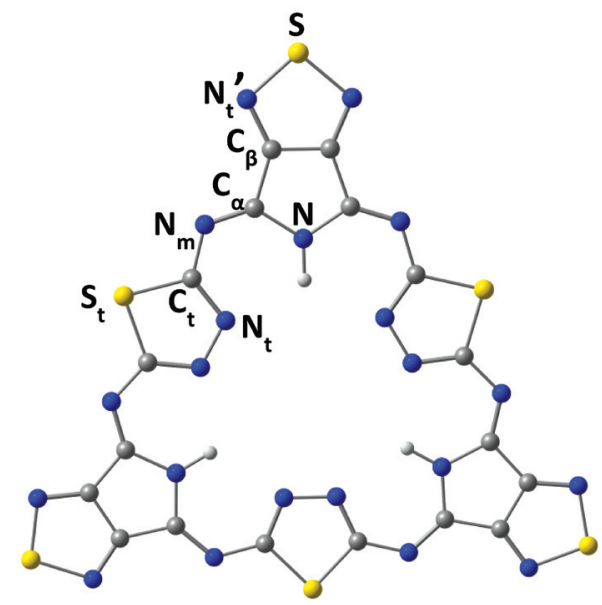

Figure 1. Molecular model of TDAHHp ( $\mathrm{D}_{3 \mathrm{~h}}$ point group) with atom labeling.

\section{Computational details}

DFT calculations for possible NH-tautomers of TDAHHp were performed with use of Gaussian 09 program package. ${ }^{[8]}$
The calculations were carried out using $\mathrm{B} 3 \mathrm{LYP}^{[9-11]}$ functional and pcseg- $2^{[12]}$ basis set $(\mathrm{C}, \mathrm{N}, \mathrm{H}, \mathrm{S})$ taken from the EMSL BSE library. Planar models of the tautomers (Figure 4) were optimized under $D_{3 \mathrm{~h}}$ (TDAHHp), $C_{3 \mathrm{~h}}$ (3PT), $C_{2 \mathrm{~V}}$ (2PT-1, 2PT-2) and $C_{\mathrm{S}}$ (1PT1, 1PT-2, 2PT-3) symmetry constraints. Vibration frequencies were calculated in the harmonic approximation for all the optimized structures. In order to simulate the shape of the infrared (IR) spectrum of TDAHHp (Figure 7), the individual bands were described by Lorentz curves with a half width of $15 \mathrm{~cm}^{-1}$. The abbreviations of the tautomers reflect "proton(s) transfer"(PT) from the main TDAHHp structure. E.g., the structures 1PT-1 and 1PT-2 can be obtained from the main TDAHHp structure by "migration" of one hydrogen from atom $\mathrm{N}$ to $\mathrm{N}_{\mathrm{t}}$ (see Figure 4), etc.

The natural bond orbital (NBO) analysis was performed as it is implemented in Gaussian 09. ${ }^{[13]}$

Quantitative QTAIM (Quantum Theory of Atoms in Molecules) analysis was performed using AIMAll software package. ${ }^{[14]}$

Electronic absorption spectrum of TDAHHp was simulated on the basis of TDDFT calculations in B3LYP/pcseg-2 approximation with use of Firefly QC package, ${ }^{[15]}$ which is partially based on the GAMESS(US) source code. ${ }^{[16]}$ Twelve low-lying electronic states for each irreducible representation of the point group $D_{3 \mathrm{~h}}$ have been taken into account within TDDFT calculations. Molecular models and orbitals demonstrated in the paper were visualized by means of Chemcraft program. ${ }^{[17]}$

\section{Results and Discussion}

\section{NH-Tautomerism and energetics of the intramolecular hydrogen bonding}

According to the results of the calculations, none of the optimized planar structures of the tautomers possesses imaginary frequencies, except for tautomer 1PT-2, in which strong repulsion between the neighboring $\mathrm{H}$ atoms appears in the planar framework. Equilibrium structures of all six $\mathrm{NH}$-tautomers are much higher in energy than the parent TDAHHp structure (see Table 1).

The lowest in energy parent TDAHHp structure contains six $\mathrm{N}_{\mathrm{t}} \ldots \mathrm{H}$ contacts (or three three-centered contacts $\mathrm{N}_{t} \ldots \mathrm{H} \ldots \mathrm{N}_{t}$ ). If one contact becomes broken due to "migration" of a hydrogen (TDAHHp $\rightarrow$ 1PT-1), the energy of the whole molecule increases by $39.2 \mathrm{~kJ} \cdot \mathrm{mol}^{-1}$ (see Table 1). Further migration of another $\mathrm{H}$ atom $(\mathbf{1 P T}-\mathbf{1} \rightarrow \mathbf{2 P T}-\mathbf{3})$ again leads to significant increase of energy.

The dependence of the relative energy of the most favorable NH-tautomers on the number of intramolecular H-bonds is almost linear (see Figure 2). It is possible to calculate the energy difference per one broken hydrogen bond (which should be approximately equal to the H-bond energy) by dividing the relative energy $\Delta E$ by the differ-

Table 1. Relative energies of NH-tautomers of TDAHHp and number of the intramolecular H-bonds.

\begin{tabular}{ccccccc}
\hline Model & TDAHHp & 1PT-1 & 2PT-1 & 2PT-2 & 2PT-3 & 3PT \\
\hline$\Delta E, \mathrm{~kJ} \cdot \mathrm{mol}^{-1}$ & 0 & 39.2 & 85.4 & 129.3 & 68.8 & 88.7 \\
$E_{\text {sum }}{ }^{(2)}\left(\mathrm{LP}(\mathrm{N}) \rightarrow \sigma^{*}(\mathrm{~N}-\mathrm{H}), \mathrm{kJ} \cdot \mathrm{mol}^{-1}\right.$ & 92.6 & 106.1 & - & - & 125.5 & 138.8 \\
$E_{\mathrm{HB}, \text { total }}, \mathrm{kJ} \cdot \mathrm{mol}^{-1}$ & 107.7 & 104.6 & - & - & 102.8 & 100.0 \\
Number of $\mathrm{H}-$ bonds & 6 & 5 & 4 & 4 & 4 & 3 \\
Energy gain per one lost $\mathrm{H}-$ bond, $\mathrm{kJ} \cdot \mathrm{mol}^{-1}$ & 0 & 39.2 & 42.7 & 64.7 & 34.4 & 29.6 \\
\hline
\end{tabular}




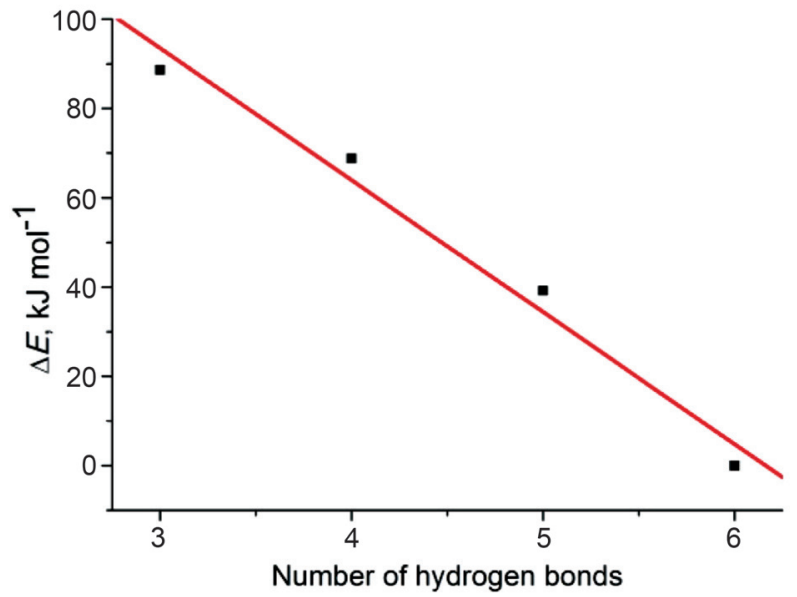

Figure 2. Relative energies of the most favorable NH-tautomers vs. number of the intramolecular H-bonds.

ence in the number of $\mathrm{H}$-bonds between corresponding tautomers. For example, in the case of 1PT-1, this value is $39.2 /(6-5)=39.2 \mathrm{~kJ} \cdot \mathrm{mol}^{-1}$.

One can estimate the energy of the intramolecular hydrogen bonding from the results of the NBO analysis. In terms of the orbital interactions, they can be treated as donor-acceptor interactions between the lone pair (LP) of the $\mathrm{N}_{\mathrm{t}}$ atom and $\sigma^{*}(\mathrm{~N}-\mathrm{H})$ antibonding orbital. The $D_{3 \mathrm{~h}}{ }^{-}$ TDAHHp structure might have been considered to correspond to the minimum due to the largest number of the intramolecular $\mathrm{N}_{\mathrm{t}}$...H contacts. However, the results of the NBO calculations distinctly demonstrate the opposite trend within the set of the most favorable models (1PT-1, 2PT-3 and 3PT). Much shorter $\mathrm{N}_{\mathrm{t}} \ldots . \mathrm{H}$ contacts in these structures $(c a .1 .95)$ as compared to the parent TDAHНp structure (ca. 2.20) stabilize the whole molecule in a greater degree (see Table 1). So, the formal largest number of $\mathrm{N}_{t} \ldots$. contacts apparently is not the reason of the pronounced stabilization of the $D_{3 \mathrm{~h}}{ }^{-}$ TDAHHp structure. Note, that the migration of the inner hydrogen atoms leads to significant changes in the bond lengths and angles in the macrocycle (see Figure S1).

Another possible way to assess the energy of a hydrogen bond $\left(E_{\mathrm{HB}}\right)$ is an approach developed by E. Espinosa et al. ${ }^{[18]}$ in the framework of AIM theory. They proposed an equation, connecting this energy with the potential energy density $V\left(\mathrm{r}_{\mathrm{CP}}\right)$ calculated at a critical point: $\mathrm{E}_{\mathrm{HB}}=0.5 \mathrm{~V}\left(\mathrm{r}_{\mathrm{CP}}\right)$. We found the bond critical points (BCPs) corresponding to hydrogen bonds in the most favorable tautomers, calculated the values of $E_{\mathrm{HB}}$ according to the above-mentioned formula, and estimated the total energy of intramolecular hydrogen bonds $E_{\mathrm{HB}, \text { total }}$ (see Table 1). Interestingly, the trend in $E_{\mathrm{HB}}$ is opposite to that calculated using NBO approach (see Figure 3). AIM calculations underestimate the energies of short $\mathrm{N}_{t} \ldots \mathrm{H}$ contacts in the structures 1PT-1, 2PT-3 and 3PT as compared to the results of the NBO analysis and do not identify BCPs for the long-range $\mathrm{N}_{t} \ldots \mathrm{H}$ interactions (see Table $\mathrm{S} 1$ ). Despite the overall increasing tendency, small differences between the values of $E_{\mathrm{HB}}$ for the tautomers as compared to $\Delta E$ (Table 1) cannot act as a main reason for stabilization of the parent TDAHHp structure.

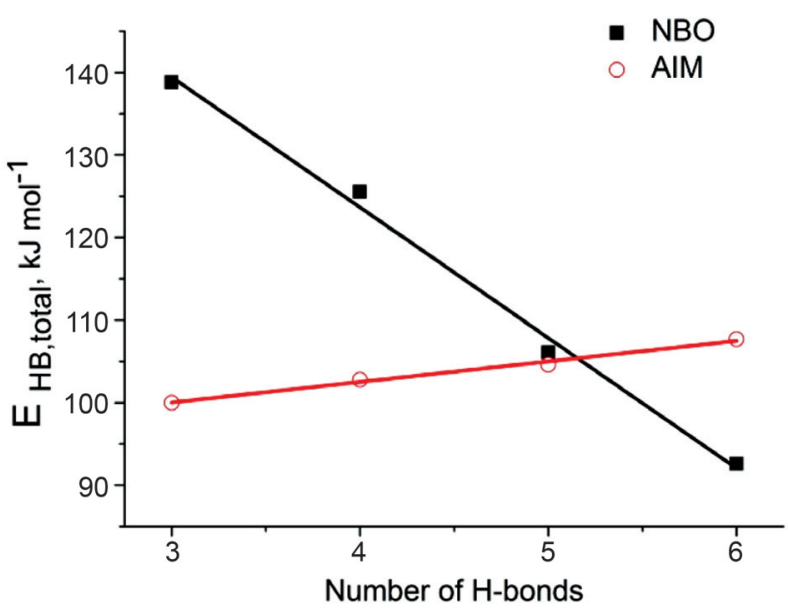

Figure 3. The dependence of the total H-bond stabilization energy on the number of hydrogen bonds for the tautomers of TDAHHp calculated using NBO and AIM approaches.

\section{Electronic absorption spectrum}

Calculations of the electronic absorption spectrum (Figure 5) predict the most intensive peak with oscillator strength of $f=0.68$ to correspond to the excitation to the lowest $1 \mathrm{E}^{\prime}$ state originating from $\mathrm{HOMO} \rightarrow \mathrm{LUMO}\left(2 \mathrm{e}^{\prime \prime} \rightarrow 1 \mathrm{e}^{\prime *}\right)$ transition. The next intensive peak at $\lambda=336 \mathrm{~nm}$ corresponds to transition $1 \mathrm{a}_{1} " \rightarrow 1 \mathrm{e}^{\prime * *}$. Detailed data are given in Table 2 . The MO level diagram for TDAHHp is shown in Figure 6 and the energies of the MOs are given in Table S2.

\section{IR Spectrum}

TDAНHр molecule possesses 138 normal modes of vibration. The vibrational representation for TDAHHp in $D_{3 \mathrm{~h}}$ symmetry is $\Gamma=16 \mathrm{~A}_{1}^{\prime}+15 \mathrm{~A}_{2}^{\prime}+31 \mathrm{E}^{\prime}+6 \mathrm{~A}_{1}^{\prime \prime}+9 \mathrm{~A}_{2}^{\prime \prime}+$ $15 \mathrm{E}^{\prime}$. Assignment of the infrared active modes was carried out by the potential energy distribution (PED) analysis among internal coordinates using the VibModule program. ${ }^{[19]}$ The $\mathrm{N}-\mathrm{H}$ stretching vibration is predicted at $3444 \mathrm{~cm}^{-1}$ (E'). The peak at $\omega=787 \mathrm{~cm}^{-1}$ can be assigned to the movement of hydrogen atoms out of the plane of the macrocycle $\left(\mathrm{A}_{2}{ }_{2}\right)$. It should be noted that the composition of most vibrational modes is complicated. Thus, the mode at $\omega=1242 \mathrm{~cm}^{-1}$ (E') corresponds to the stretching of $\mathrm{S}_{\mathrm{t}}-\mathrm{C}_{\mathrm{t}}$ (contribution $\sim 15$ $\%), \mathrm{N}_{\mathrm{m}}-\mathrm{C}_{\mathrm{t}}(\sim 12 \%), \mathrm{N}_{\mathrm{t}}-\mathrm{C}_{\mathrm{t}}(\sim 23 \%)$ bonds and in-plane bending of $\mathrm{N}-\mathrm{H}(\sim 15 \%)$. The vibration mode at $\omega=1444 \mathrm{~cm}^{-1}$ (E') corresponds mostly to the stretching of $\mathrm{C}_{\alpha}-\mathrm{N}_{\mathrm{m}}(\sim 30 \%)$ and $\mathrm{C}_{\mathrm{t}}-\mathrm{N}_{\mathrm{t}}(\sim 30 \%)$ bonds. The main contribution $(\sim 70 \%)$ to the modes at $1680 \mathrm{~cm}^{-1}\left(\mathrm{E}^{\prime}\right)$ and $1686 \mathrm{~cm}^{-1}\left(\mathrm{E}^{\prime}\right)$ stems from the stretching of $\mathrm{C}_{\alpha}-\mathrm{N}_{\mathrm{m}}$ bond. Note, that the region from 1800 to $3400 \mathrm{~cm}^{-1}$ contains no peaks.

\section{Conclusions}

The tautomeric behaviour of thiadiazole annelated hemihexaphyrazine (TDAHHp) was studied for the first time by means of DFT calculations. The parent TDAHHp 

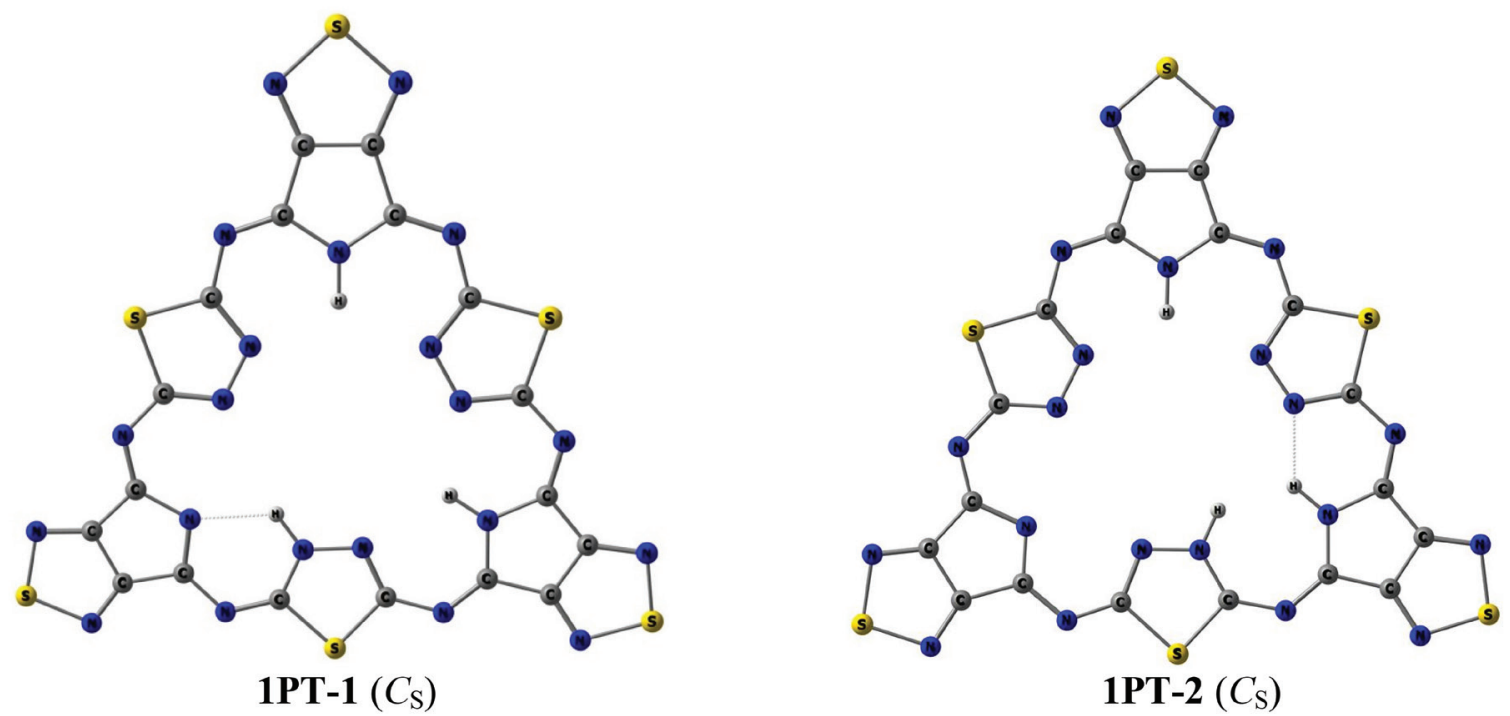

1PT-2 $\left(C_{\mathrm{S}}\right)$
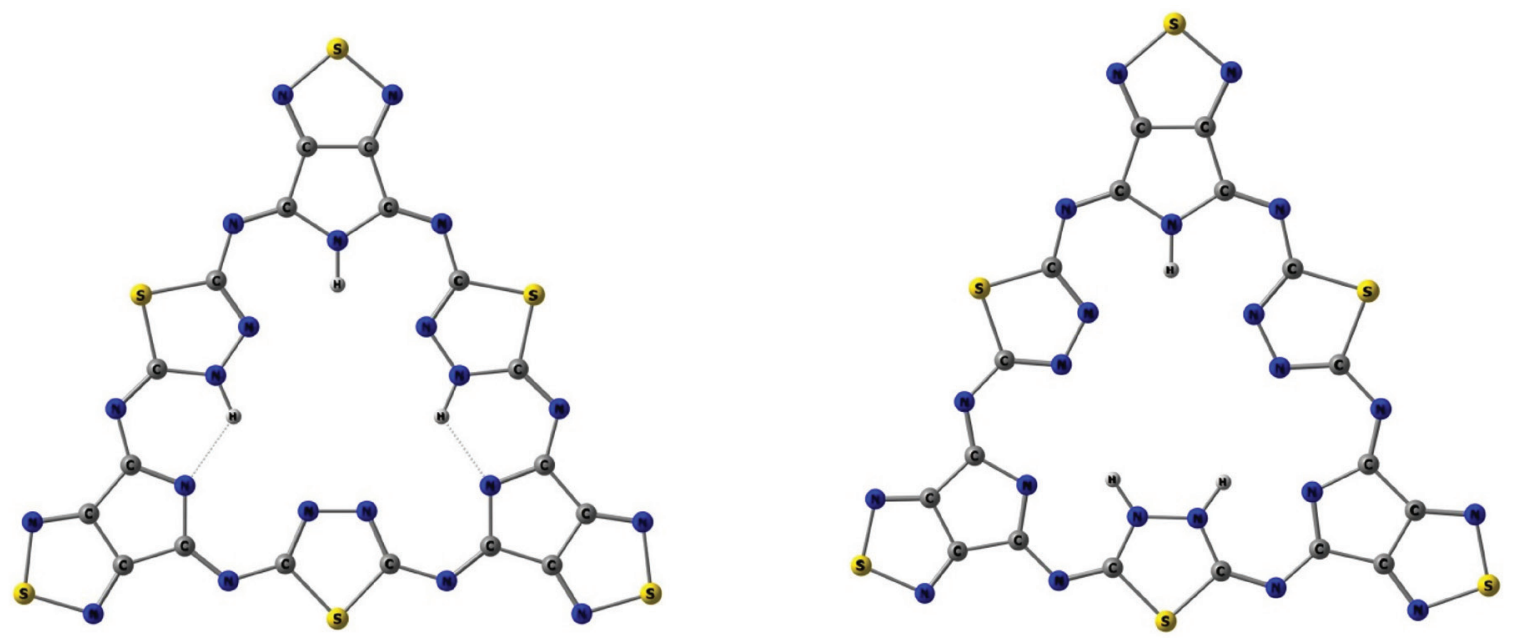

2PT-1 $\left(C_{2 \mathrm{~V}}\right)$
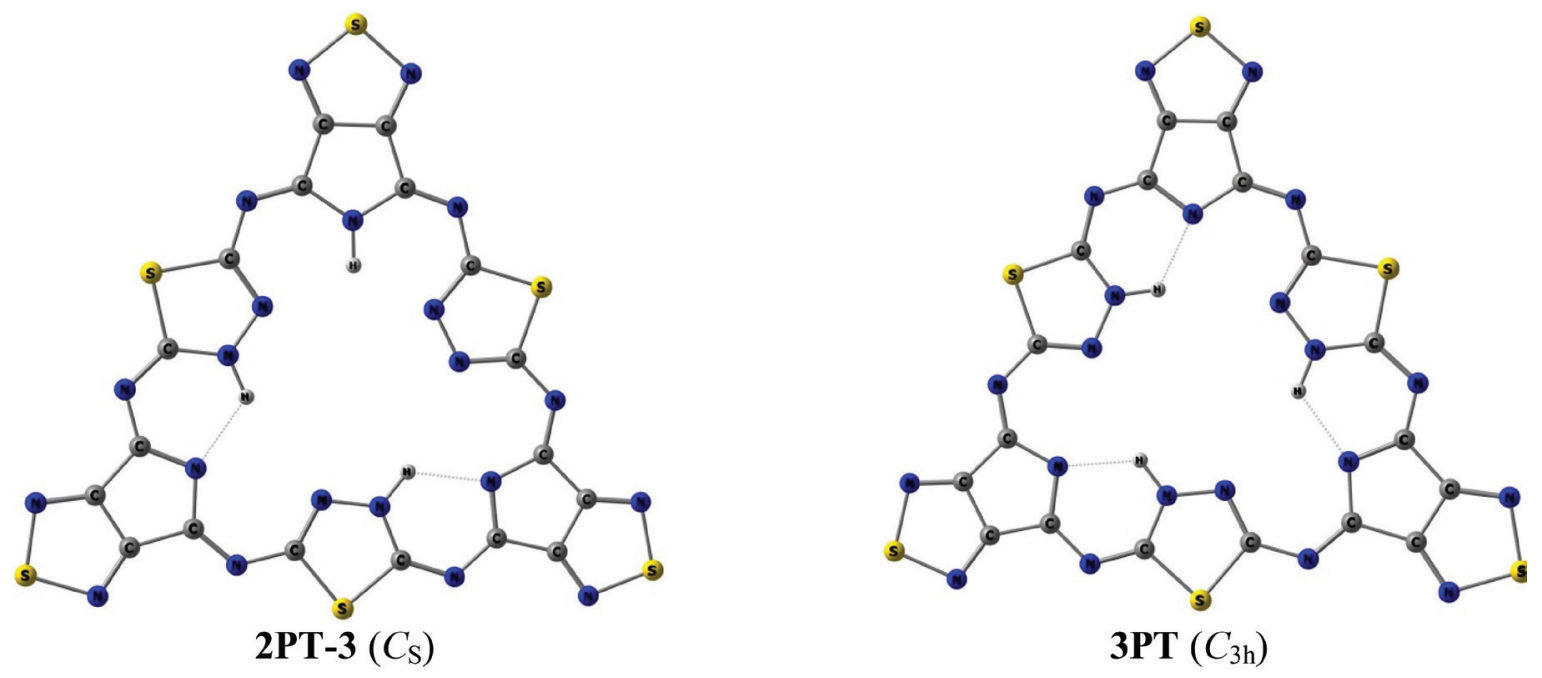

Figure 4. Models of possible tautomers of TDAHHp. 


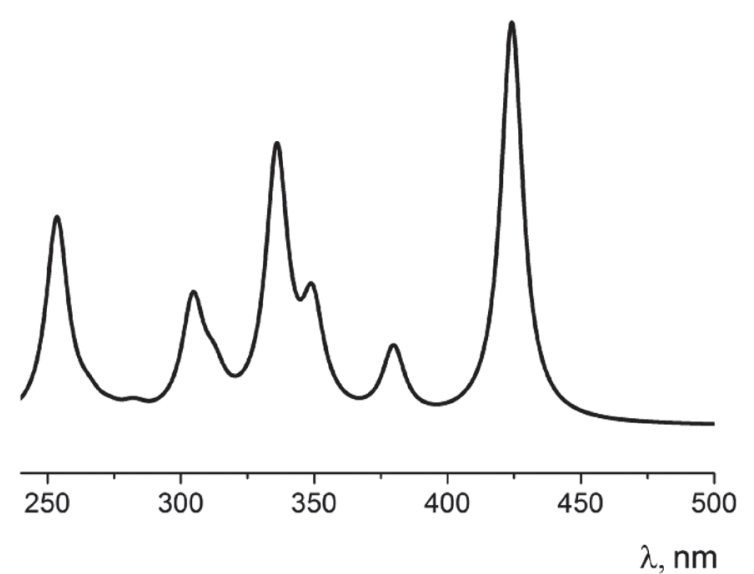

Figure 5. Calculated electronic spectrum of TDAHHp.

structure corresponds to the minimum of energy, while the other NH-tautomers are much $\left(39.2 \mathrm{~kJ} \cdot \mathrm{mol}^{-1}\right.$ and more) higher in energy. Thus, the conformational behaviour of TDAHHp exhibits both qualitative and quantitative similarity with that of the previously studied $\mathrm{C}_{30} \mathrm{H}_{15} \mathrm{~N}_{15} \mathrm{~S}_{3}$ macrocycle. ${ }^{[5]}$ However, NBO and AIM calculations performed in the present study provide another point of view on the pronounced stability of the main $D_{3 \mathrm{~h}}$ structure of TDAHHp as compared to ${ }^{[5]}$. NBO calculations of energetics of intramolecular hydrogen bonding indicate that several short N...H bonds in the tautomers stabilize the whole structure in a greater degree as compared to six long $\mathrm{N}_{\mathrm{t}} \ldots \mathrm{H}$ contacts in the parent TDAHHp structure. AIM calculations demonstrate the opposite trend in changing of the total hydrogen bonding energy within the series of the tautomers, but nevertheless, the differences

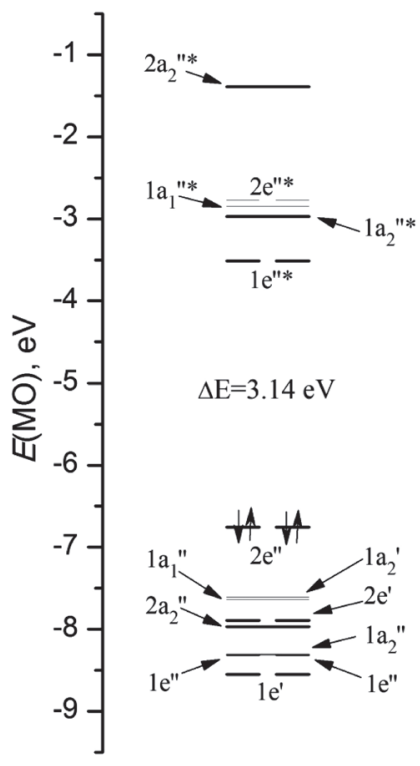

Figure 6. MO level diagram for TDAHHp.

between the values of $E_{\mathrm{HB}, \text { total }}$ are about 10 times less as compared to the corresponding $\Delta E$ magnitudes. Therefore, intramolecular hydrogen bonding is not an interaction stabilizing the main $D_{3 \mathrm{~h}}$-structure of TDAHHp as might have been thought from qualitative point of view. Investigations of the similar macroheterocyclic systems can shed further light on the true reason of tautomeric preference.

Acknowledgements. We acknowledge Russian Science Foundation (grant № 17-73-10198) for financial support. We also thank Dr. Oleg A. Pimenov for the valuable suggestions concerning AIM calculations.

Table 2. Calculated composition of the lowest excited E' states, excitation energies and oscillator strengths for TDAHHp.

\begin{tabular}{|c|c|c|c|c|}
\hline \multirow{2}{*}{ State } & \multirow{2}{*}{ Composition (\%) } & \multicolumn{2}{|c|}{ Excitation energy } & \multirow{2}{*}{$\frac{\text { Oscillator strength }}{\mathrm{f}^{a}}$} \\
\hline & & $\mathrm{E}, \mathrm{eV}$ & $\lambda_{\text {calc }}, \mathrm{nm}$ & \\
\hline $1 E^{\prime}$ & $2 \mathrm{e}^{\prime \prime} \rightarrow 1 \mathrm{e}^{\prime *}(96)$ & 2.9 & 424 & 0.68 \\
\hline \multirow[t]{2}{*}{$2 \mathrm{E}^{\prime}$} & $2 \mathrm{e}^{\prime \prime} \rightarrow 1 \mathrm{a}_{2}{ }^{\prime *}(84)$ & 3.3 & 380 & 0.12 \\
\hline & $2 \mathrm{e}^{\prime \prime} \rightarrow 2 \mathrm{e}^{\prime *}(10)$ & & & \\
\hline \multirow[t]{3}{*}{$4 \mathrm{E}^{\prime}$} & $1 \mathrm{a}_{1} " \rightarrow 1 \mathrm{e}^{\mathrm{N} *(7)}$ & 3.5 & 349 & 0.17 \\
\hline & $2 \mathrm{e}^{\prime \prime} \rightarrow 1 \mathrm{a}_{1} " *(68)$ & & & \\
\hline & $2 \mathrm{e}^{\prime \prime} \rightarrow 2 \mathrm{e}^{\prime *}(19)$ & & & \\
\hline $5 \mathrm{E}^{\prime}$ & $1 \mathrm{a}_{1} " \rightarrow 1 \mathrm{e}^{\prime *}(87)$ & 3.7 & 336 & 0.44 \\
\hline \multirow[t]{3}{*}{$6 \mathrm{E}^{\prime}$} & $1 \mathrm{e}^{\prime \prime} \rightarrow 1 \mathrm{e}^{\prime *}(33)$ & 4.0 & 312 & 0.06 \\
\hline & $1 \mathrm{a}_{2} " \rightarrow 1 \mathrm{e}^{\prime *}(39)$ & & & \\
\hline & $2 \mathrm{a}_{2} " \rightarrow 1 \mathrm{e}^{\prime *}(20)$ & & & \\
\hline \multirow[t]{3}{*}{$7 \mathrm{E}^{\prime}$} & $1 \mathrm{e}^{\prime \prime} \rightarrow 1 \mathrm{e}^{\prime *}(14)$ & 4.1 & 305 & 0.19 \\
\hline & $1 \mathrm{a}_{2} " \rightarrow 1 \mathrm{e}^{\prime *}(7)$ & & & \\
\hline & $2 \mathrm{a}_{2} " \rightarrow 1 \mathrm{e}^{\prime *}(70)$ & & & \\
\hline \multirow[t]{3}{*}{$12 \mathrm{E}^{\prime}$} & $1 \mathrm{e}^{\prime \prime} \rightarrow 1 \mathrm{a}_{2} " *(28)$ & 4.9 & 254 & 0.34 \\
\hline & $1 \mathrm{a}_{2} " \rightarrow 2 \mathrm{e}^{\mathrm{a}}(6)$ & & & \\
\hline & $2 \mathrm{e}^{\prime \prime} \rightarrow 2 \mathrm{a}_{2} " *(43)$ & & & \\
\hline
\end{tabular}

${ }^{a}$ Only the excited states with an oscillator strength larger than 0.05 are reported. 


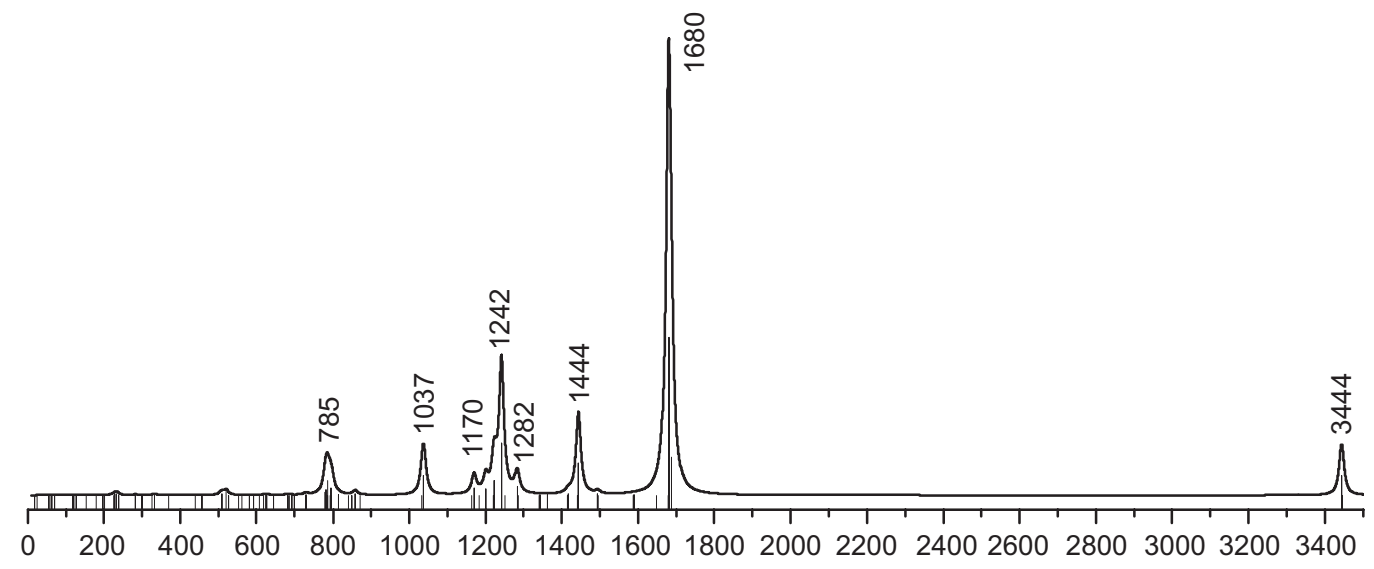

Figure 7. Simulated IR spectrum of TDAHHp.

\section{References}

1. Strenalyuk T., Samdal S., Volden H.V. J. Phys. Chem. A 2008, $112,4853-4860$.

2. Stępień M., Latos-Grażyński L. Aromaticity and Tautomerism in Porphyrins and Porphyrinoids. In: Aromaticity in Heterocyclic Compounds (Krygowski T.M., Cyrański M.K., Eds.) Berlin, Heidelberg: Springer, 2009. p. 83-153.

3. Zakharov A.V., Stryapan M.G., Islyaikin M.K. J. Mol. Struct.: THEOCHEM 2009, 906(1-3), 56-62.

4. Zakharov A.V., Shlykov S.A., Danilova E.A., Krasnov A.V., Islyaikin M.K., Girichev G.V. Phys. Chem. Chem. Phys. 2009, $11,8570-8579$.

5. Zhabanov Y.A., Zakharov A.V., Shlykov S.A., Trukhina O.N., Danilova E.A., Koifman O.I., Islyaikin M.K. J. Porphyrins Phthalocyanines 2013, 17, 220-228.

6. Cirera B., Trukhina O., Björk J., Bottari G., RodríguezFernández J., Martin-Jimenez A., Islyaikin M.K., Otero R., Gallego J.M., Miranda R., Torres T., Ecija D. J. Am. Chem. Soc. 2017, 139, 14129-14136.

7. Vogt N., Savelyev D.S., Giricheva N.I., Islyaikin M.K., Girichev G.V. J. Phys. Chem. A 2016, 120, 8853-8861.

8. Frisch M.J., Trucks G.W., Schlegel H.B., Scuseria G.E., Robb M.A., Cheeseman J.R., Scalmani G., Barone V., Petersson G.A., Nakatsuji H., Li X., Caricato M., Marenich A., Bloino J., Janesko B.G., Gomperts R., Mennucci B., Hratchian H.P., Ortiz J.V., Izmaylov A.F., Sonnenberg J.L., Williams-Young D., Ding F., Lipparini F., Egidi F., Goings J., Peng B., Petrone A., Henderson T., Ranasinghe D., Zakrzewski V.G., Gao J., Rega N., Zheng G., Liang W., Hada M., Ehara M., Toyota K.,
Fukuda R., Hasegawa J., Ishida M., Nakajima T., Honda Y., Kitao O., Nakai H., Vreven T., Throssell K., Montgomery J.A., Jr. Peralta J.E., Ogliaro F., Bearpark M., Heyd J.J., Brothers E., Kudin K.N., Staroverov V.N., Keith T., Kobayashi R., Normand J., Raghavachari K., Rendell A., Burant J.C., Iyengar S.S., Tomasi J., Cossi M., Millam J.M., Klene M., Adamo C., Cammi R., Ochterski J.W., Martin R.L., Morokuma K., Farkas O., Foresman J.B., Fox D.J. Gaussian 09, Revision D.01 Gaussian, Inc., Wallingford CT, 2016.

9. Becke A.D. J. Chem. Phys. 1993, 98, 5648-5652.

10. Lee C., Yang W., Parr R.G. Phys. Rev. B 1988, 37, 785-789.

11. Vosko S.H., Wilk L., Nusair M. Can. J. Phys. 1980, 58, 1200 1211.

12. Jensen F. J. Chem. Theory Comput. 2014, 10, 1074-1085.

13. Glendening E.D., Reed A.E., Carpenter J.E., Weinhold F. NBO Version 3.1.

14. Keith T.A. AIMAll (Version 16.01.09) TK Gristmill Software, Overland Park KS, USA, 2017 (aim.tkgristmill.com).

15. Granovsky A.A. Firefly version 8. www http://classic.chem. msu.su/gran/firefly/index.html.

16. Schmidt M.W., Baldridge K.K., Boatz J.A., Elbert S.T., Gordon M.S., Jensen J.H., Koseki S., Matsunaga N., Nguyen K.A., Su S., Windus T.L., Dupuis M., Montgomery J.A. J. Comput. Chem. 1993, 14, 1347-1363.

17. Zhurko G.A. Chemcraft-graphical program for visualization of quantum chemistry computations. https://chemcraftprog.com.

18. Espinosa E., Molins E., Lecomte C. Chem. Phys. Lett. 1998, 285, 170-173.

19. Vishnevskiy Yu.V., Zhabanov Yu.A. J. Phys. Conf. Ser. 2015, 633(1), 012076. 